DOI: 10.17707/AgricultForest.62.1.36

\author{
Svetlana ŠLIKOVÁ, Soňa GAVURNÍKOVÁ, \\ Roman HA ̌́ANA, Martina MINÁRIKOVÁ, Edita GREGOVÁ ${ }^{I}$
}

\title{
DEOXYNIVALENOL IN GRAINS OF OATS AND WHEAT PRODUCED IN SLOVAKIA
}

\begin{abstract}
SUMMARY
The mycotoxin survey focused on natural occurrence of Deoxynivalenol (DON) in mature grains of oats and wheat produced by Slovak fields in 2013. DON is one of the most predominant mycotoxins occurring in grains of cereals produced by Fusarium fungi after the attack of plants. A total of 10 oat samples from 9 locations and 178 wheat samples from 89 locations were collected in 2013. The samples were collected directly from growers. A commercial ELISA kit was used to determine the DON concentration in wheat samples with the limit of detection < 0.2 mg.kg-1 (ppm) and limit of quantification $0.2 \mathrm{mg} . \mathrm{kg}-1$ (ppm). Mycotoxin was found in $30.0 \%$ (max. $0.49 \mathrm{mg} \cdot \mathrm{kg}-1$ ) of oat and $82.0 \%$ (max. 5.10 mg.kg-1) of wheat samples. The natural mean DON contamination of oat samples was lower than in wheat samples. Only wheat samples had higher DON content than defined by the regulations of the European Union (EU) for this mycotoxin. Results indicated that the location had a significant effect on the DON content $(p<0.000)$ in wheat grains what was connected with climatic conditions.
\end{abstract}

Keywords: mycotoxin, Avena sativa L., Triticum aestivum L., locations

\section{INTRODUCTION}

Oats and wheat are among the most significant crops grown in Slovakia. However, the oat-growing area has diminished in the past few years. Grain of these crops is used for food and feed purposes. Nowadays, oat grain is often a part of breakfast cereals; oat bran and flour are added to wheat bread or various bakery products because of its beneficial effect on human health. The Food and drug administration (FDA) accepted the oat bran as a food that can lower the risk of heart disease due to physiological effects of $\beta$-D-glucan (a structural component of cell walls in oat bran) on the mammalian digestive system which lowers serum cholesterol (FDA, 1997). In addition, it is exploited in the prevention of heart and vascular diseases and some cancer types, especially the

\footnotetext{
${ }^{1}$ Svetlana Šliková, Soňa Gavurníková, Roman Hašana, Edita Gregová (corresponding author: slikova@vurv.sk), 1National Agriculture and Food Centre, Research Institute of Plant Production, Bratislavská cesta 122, 92168 Piešt’any, SLOVAK REPUBLIC, Martina Mináriková, Department of Theoretical Geodesy, Slovak University of Technology, Radlinského 11, 81368 Bratislava, SLOVAK REPUBLIC

Paper presented at the $6^{\text {th }}$ International Scientific Agricultural Symposium "AGROSYM 2015 ".

Notes: The authors declare that they have no conflicts of interest. Authorship Form signed online.
} 
cancers of digestive system. The spikes and panicles of these crops are attacked by fungi from Fusarium genus several times a year which are able to produce various types of mycotoxins contaminating grains during the pathogenesis. Several Fusarium spp. are widespread pathogens on small-grain cereals (soft and durum wheat, barley, oats, rye and triticale) all around the world, including all European cereal-growing areas. In the Slovak Republic (SR), the data about the occurrence of genus Fusarium on oats is not known as much as in wheat where F. graminearum Schwabe and F. culmorum (W. G. Sm.) Sacc are the most common. However, F. poae or F. graminearum have been predominating in the past few years (Sudyova and Slikova, 2011). Fungi Fusarium can produce different types of mycotoxins (Bottalico and Perrone, 2002). Trichothecenes is one of the major mycotoxin groups which was categorized into four types. Type A is mainly represented by T-2 and HT-2 toxin; type B by DON, nivalenol and their acetylated precursors; type $\mathrm{C}$ by crotocin and baccharin; and type $\mathrm{D}$ by tratoxin and roridin. Research into the natural occurrence of mycotoxins has shown that DON is one of the most frequently found mycotoxins in foodstuffs (Schollenberger et al., 2005) and in feed (Streit et al., 2013). Uhling (2013) reported that 46 metabolites (all of fungal origin) were detected in barley, oats and wheat samples (these were collected during "worst-case" season with weather conditions favouring fungal infection in Southern Norway). The analyses confirmed high prevalence and relatively high concentrations of type-A and -B trichothecenes (deoxynivalenol and HT-2 toxin). Mycotoxin DON has been associated with human gastroenteritis, and in experimental animal models, acute DON poisoning causes emesis, whereas chronic low-dose exposure elicits anorexia, growth retardation, immunotoxicity as well as impaired reproduction and development resulting from maternal toxicity (Pestka, 2010). The toxicity of the mycotoxin has lead many countries to set up regulations for its control in grains and food products that are intended for human or animal consumption. The maximum allowed limits for DON have been set by the European Commission in unprocessed wheat and food products. EC Regulation 1126/2007 applied to unprocessed cereals other than durum wheat, oats and maize is 1250 $\mu \mathrm{g} . \mathrm{kg}-1$ and unprocessed durum wheat and oats is $1750 \mu \mathrm{g} . \mathrm{kg}-1$.

The present paper reports the results of the survey on natural occurrence of DON in the samples of oat and wheat grains obtained after the harvest of oats and wheat grown in different localities of Slovakia.

\section{MATERIAL AND METHODS}

The wheat and oat grains were obtained during the 2013 growing season from 9 locations (oat samples) and 89 locations always from 2 farmers' fields (wheat samples) of Slovakia (Fig. 1). The samples were collected from grains of wheat cultivars and oat cultivars which were stored by growers in halls or granaries immediately after harvesting. The incremental samples were mixed and put in paper bags and stored in cool place (cca. $2000 \mathrm{~g}$ ). After grinding the full lot sample, a subsample ( $5 \mathrm{~g})$ was taken for analysis. A commercial ELISA kit 
was used to determine the DON concentration in the samples (Ridascreen Fast DON, RBiopharm, Darmstadt, Germany) with limit of detection < 0.2 mg.kg-1 (ppm) and limit of quantification $0.2 \mathrm{mg} . \mathrm{kg}-1$ (ppm). The grain samples were ground (Ultra Centrifugal Mill, type ZM 100, Retsch, Haan, Germany) with sieve size $1.00 \mathrm{~mm}$. Then $100 \mathrm{ml}$ of distilled water was added to $5 \mathrm{~g}$ of each sample and the mixture filtered. The filtrate, in aliquots of $50 \mu \mathrm{l}$, measured. The absorbencies of the wells were determined photometrically at $450 \mathrm{~nm}$ (MRX II, Dynex Technologies, Chantilly, Virginia, USA) and the DON concentrations were calculated in mg.kg-1 by Revelation Version 4.25 (Dynex Technologies). The data were evaluated by descriptive statistics (mean, median and max values). Statistical analysis was performed using SPSS software 11.5 (SPSS, Chicago, Illinois, USA) and the statistical significance levels were set at $95 \%(\mathrm{p}<0.05)$ and $99 \%(\mathrm{p}<0.01)$.

\section{RESULTS AND DISCUSSION}

Wheat samples obtained after harvesting crops in 2013 contained on average 4.4 more mycotoxin DON content than oat samples. The number of analysed oat samples is low; however, they were collected in various localities all around the territory of Slovakia (Fig. 1). Growing season in Slovakia in 2013 was quite favourable for the development of fusaria producing DON as shown in the results of the occurrence of mycotoxin DON in samples (Tab. 1). Total precipitation in Slovakia in 2013 was $127 \mathrm{~mm}$ in May and $112 \mathrm{~mm}$ in June (mean monthly precipitation was calculated by data obtained from about 600 meteorological weather stations in Slovakia by the Slovak Hydrometeorological Institute (Lapin, 2015). These results correspond with previously published data where there was a positive relationship between rainfall and DON content in wheat. Previous data were obtained from samples taken from wheat cultivated between 2004 - 2006 (Slikova et al., 2008). High mean DON content (0.93 mg.kg-1) in wheat samples in 2010 (Slikova et al., 2013) probably related to precipitation (mean precipitation in Slovakia was $235 \mathrm{~mm}$ in May and $148 \mathrm{~mm}$ in June, Lapin, 2015). There was a different situation with the occurrence of DON in wheat samples in 2011 when mean DON content was 0.30 mg.kg-1, in May = $67 \mathrm{~mm}$ and June $=124 \mathrm{~mm}$ (Slikova et al., 2013). The weather was similar in 2012 when we found low mean DON content in samples $(0.27$ mg.kg-1; not published), precipitation was $46 \mathrm{~mm}$ in May and $103 \mathrm{~mm}$ in June (Lapin, 2015). Weather conditions during the flowering and ripening stages of wheat were critical for Fusarium head blight development. The study showed that high temperatures in central Poland in July and August in 2009 accompanied by high rainfall in July were responsible for high DON levels in wheat (Wiśniewska et al., 2014). The contamination of oat grain by mycotoxin DON in Slovakia was only detected after artificial infection of panicles by fusaria (Slikova et al., 2010). Research into natural occurrence of mycotoxin DON in oat samples obtained from the crops in 2013 in Slovakia showed that DON content was low (Tab. 1). 


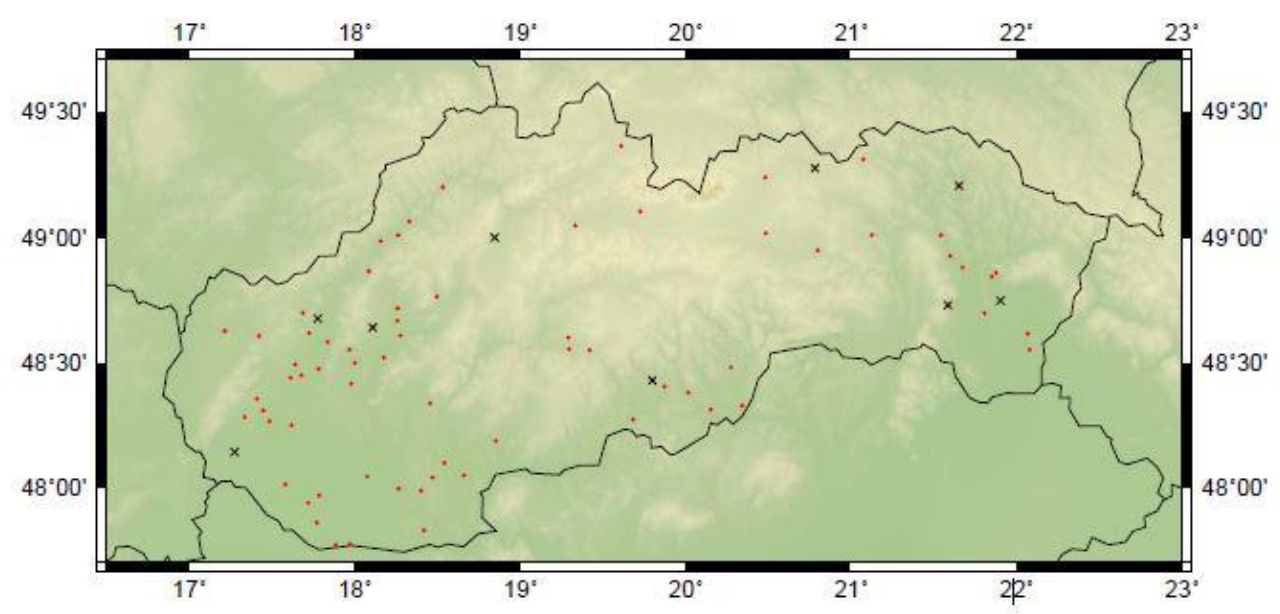

Figure 1. Location of sampling sites in the Slovak Republic from which oat samples $(\mathrm{n}=9$; cross $)$ and wheat samples $(\mathrm{n}=89$; spot $)$ were collected in 2013

Table 1. Deoxynivalenol, prevalence, median, mean and maximum detected amount of grain grown in Slovakia (2013)

\begin{tabular}{|l|c|c|c|c|c|}
\hline \multicolumn{1}{|c|}{ Sample } & N. samples & $\begin{array}{c}\text { Positive } \\
\text { samples } \\
(\%)\end{array}$ & $\begin{array}{c}\text { Median } \\
\left(\mathrm{mg} . \mathrm{kg}^{-1}\right)\end{array}$ & $\begin{array}{c}\text { Maximum } \\
\left(\mathrm{mg} \cdot \mathrm{kg}^{-1}\right)\end{array}$ & $\begin{array}{c}\text { Mean } \\
\left(\mathrm{mg}^{\left.-\mathrm{kg}^{-1}\right)}\right.\end{array}$ \\
\hline Wheat & 178 & 82.0 & 0.34 & 5.10 & 0.74 \\
\hline Oats & 10 & 30.0 & 0.20 & 0.49 & 0.17 \\
\hline $\begin{array}{l}\text { Wheat }+ \\
\text { Oats }\end{array}$ & 188 & 80.9 & 0.33 & 5.10 & 0.71 \\
\hline
\end{tabular}

a Positive samples: mycotoxin concentration above detection limit $>0.2 \mathrm{mg} . \mathrm{kg}-1$

ANOVA has revealed that don occurrence in wheat samples obtained from various localities in slovakia was different (tab. 2). Mean don content lower than $0.2 \mathrm{mg} . \mathrm{kg}-1$ was found in samples obtained from 18 localities, the presence of mycotoxin ranging from 0.2 to $1.25 \mathrm{mg} . \mathrm{kg}-1$ was found in 146 localities and there was mean don content more than 1.25 mg.kg-1 in samples from 14 localities. Two samples were obtained from every locality (i.e. From two fields) and their contamination within the locality was very similar in some cases. Excess contamination of both samples was detected in samples from 6 localities. The occurrence of at least one sample with excess don content was found in 16 localities. Don content in samples from these localities ranged from 0.33 to 5.10 mg.kg- ${ }^{1}$ 
Table 2. ANOVA of mycotoxin DON content

\begin{tabular}{|l|c|c|c|c|c|}
\hline $\begin{array}{l}\text { Source of } \\
\text { variantion }\end{array}$ & Sum of Squares & $\begin{array}{c}\text { Degree } \\
\text { of freedom }\end{array}$ & Mean Square & F-value & P-value \\
\hline Location & 137.166 & 88 & 1.559 & 3.516 & 0.000 \\
\hline Error & 39.454 & 89 & 0.443 & & \\
\hline Total & 273.841 & 178 & & & \\
\hline
\end{tabular}

\section{CONCLUSIONS}

Nowadays, growers are well-informed about the occurrence of mycotoxin DON in the grains of cereals grown in EU countries. Results from analyzing samples of wheat and oat grain obtained from the crops in 2013 showed that the contamination in oat was several times lower than in wheat. Mean contamination of wheat samples relates to very favourable conditions for the development of diseases caused by fusaria in that year. The contamination of samples from one locality (two fields) was more or less the same. Significant differences in the contamination of samples in different localities were detected. This implies that mainly in years with favourable conditions for the development of Fusarium head blight, it would be suitable to choose such places for collecting samples which take into account the diversity of the country in monitoring the mycotoxin as in some localities both samples were without contamination and in some they were highly contaminated.

\section{ACKNOWLEDGEMENTS}

This work was supported by OP Research and Development: Development of new types of genetically modified plants with farm traits (ITMS 26220220189), by the European Regional Development Fund and by the Science and Research Support Agency (No. APVV-0398-12) of the Slovak Republic.

\section{REFERENCES}

Bottalico, A., Perrone, G. (2002). Toxigenic Fusarium species and mycotoxins associated with heat blight in small-grain cereal in Europe, Eur. J. Plant Pathol., 108, pp. (611 624).

Food and Drug Administration (1997). FDA allows whole oat foods to make health claim on reducing the risk of heart disease (21 Code of Federal Regulations 101.81) (62 Federal Register 3584, 23 January 1997). Available at www: http://www.fda.gov/default.htm/ Last updated:11.08.2015.

Lapin M. (2015). Dlhodobý režim úhrnov atmosférických zrážok na Slovensku. (Longterm regime of precipitation in Slovakia), Slovak Hydrometeorological Institute in Bratislava, Available at http://www.dmc.fmph.uniba.sk/public_html/climate/climate.html Last updated: 13.7.2015.

Pestka, J. J. (2010). Deoxynivalenol: mechanisms of action, human exposure, and toxicological relevance, Arch. Toxicol, 84, pp. (663 - 679). 
Schollenberger, M., Müller, H. M., Rüfle, M., Suchy, S., Planck, S., Drochner, W. (2005). Survey of Fusarium toxins in foodstuffs of plant origin marketed in Germany, International Journal of Food Microbiology, 97, pp. (317 - 326).

Siuda, R., Grabowski, A., Lenc, L., Ralcewicz, M., Spychaj-Fabisiak, E. (2010). Influence of the degree of fusariosis on technological traits of wheat grain, International Journal of Food Science \& Technology, 45, pp. (2596 - 2604). 